\title{
The Moving of Seaport from Labuhan Deli to Belawan in the Period of 1863-1942
}

\author{
Suprayitno ${ }^{1}$, Ratna $^{2}$, Rohani $^{3}$, Ganie $^{4}$, Handoko $^{5}$ \\ ${ }^{1,2}$ Departement of History, Faculty of Cultural Science, Universitas Sumatera Utara, Indonesia \\ ${ }^{3,4}$ Departement of English Literature, Faculty of Cultural Science, Universitas Sumatera Utara, Indonesia \\ ${ }^{5}$ Postgraduate Program of Departement of History, Faculty of Cultural Science, Universitas Sumatera \\ Utara, Indonesia \\ nisanaceh@gmail.com
}

\begin{abstract}
Plantation economic growth has the impact on development in various aspects. One of them is shipping and trade development. Before the existence of plantations in East Sumatera, shipping and trade in Medan were centered at Labuhan Deli as a river-port. Since big ships could not sail on the river, it was considered not effective and efficient anymore. Therefore, the Dutch Colonial Government planned to build a seaport located on the sea coast so that loading and unloading would be easy to do, and they selected Belawan to be the new seaport. The research problems were how about the existence of Labuhan Deli by the policy of the Dutch Government on moving the seaport to Belawan and what was their reason for it, and how about shipping and trade business in Belawan. This research used archives and other writing materials from the period of the Dutch Colonial Government in Medan and used historical method. The objective of the research was to find out whether plantation economic condition could change various aspects, including shipping and trade at the time. The result of this research was expected to become the reference for the writing on advanced maritime history, particularly on seaport.
\end{abstract}

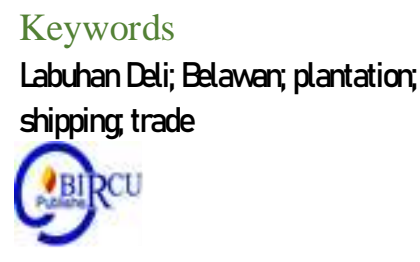

\section{Introduction}

A seaport is a place equipped by buildings such as wharf, mooring posts, and its other equipment for cargo and passengers. Seaports in Indonesia used to be located by the rivers, and ships and boats could dock and drop anchors. It is interesting to analyze seaports since they are the seaward gates for merchants to market their commodities from different places. These activities have the impact on the surrounding places in economic, cultural, social, and political matters. The construction of Belawan harbor was initiated by train company, Deli Spoorweg Maatschappij (DSM) since it was built to facilitate the transportation of plantation products.

Before Belawan harbor was developed, the activities of shipping and trade were at Labuhan Deli. Then the seaport was moved to Belawan due to sedimentation from the Deli River; besides that, plantation economy rapidly developed and needed a wider place for export and import activities in which big steam ships could gather plantation products transported by trains from various places in the hinterland. Riyardi et al (2019) stated that government regulations guide the assessment of user satisfaction with services provided by the government to ensure that the government serves the user. The government's policy on making Belawan as the main seaport in East Sumatera Residence had also influenced the hinterland areas which transported their plantation products to Belawan harbor. 


\section{Research Methods}

The primary and secondary data were gathered by studying archives and searching for supporting data such as books and journals related to the history of seaports in the Library of North Sumatera Province, the National Library of the Republic of Indonesia, and other libraries. The research used historical analysis method to find out facts, experiences, and development in the Dutch colonial period. The primary data were related to seaports which included policy, organization, and trading and shipping companies in Belawan harbor during the colonial period in East Sumatera. The supporting data were obtained from the government agencies which had the authority and relation to Belawan harbor. Data gathering was intended to get document, archives, maps, records, etc., as the references.

\section{Discussion}

\subsection{Labuhan Deli in Pre and Post Colonial Era}

As the center of Kesultanan Deli Government, Labuhan Deli also functioned as a seaport, located half a mile toward the downstream from the estuary. ${ }^{1}$ The name, Labuhan, is closely related to the Labuhan River. ${ }^{2}$ Its town structure is highly identical with the other traditional Melayunese Kingdoms in Sumatera. This system was established by the existence of the authority in the strategic and downstream areas crowded with business activities. Merchants from the upstream of the river and from the foreland areas who wanted to sell their agricultural or forest products were imposed tax rate on them. The tax was used as the capital for establishing the Melayunese traditional kingdom. ${ }^{3}$ Native authorities such Deli, Serdang, and Asahan assumed that it was more advantageous to deal with the British Government in Penang than with the Dutch Government. ${ }^{4}$

Anderson arrived in Deli and saw the local people make boats which were called penjajab. He also saw many merchants and people who caught a kind of shark called, juparang which were sold to the Chinese merchants for medicines. He found many exported commodities of agricultural and forest products such as pepper, rice, tobacco, dried fish, gambier (Uncaria gambir), piled up on the seaport.

Anderson arrived in Deli on the $16^{\text {th }}$ of January, 1823 . He saw local people build boats and ships called, panjajap. He also saw them catch a kind of shark called, juparang and sold to Chinese merchants to be used for medicines. He also reported agricultural and forest products exported through Deli such as pepper, rice, tobacco, dried fish, gambier, camphor, wax, horses, slaves, sulfur, ///gold, and ivories Imported commodities sent from the other places to Labuhan Deli were any types of cloth, opium, earthenware, guns, gun powder, and salt. Shipping and trade activities as well as export and import in Labuhan Deli were controlled by a harbormaster, Ahmed, while tariff and tax were collected by a mata-mata, a woman whose name was Che Laut (Cik Laut).

The Dutch government had successfully controlled most of the east coast of Sumatera through Siak Treaty on the $1^{\text {st }}$ of February, 1858. One of its clauses was that Kesultanan Siak and all its colonies became parts of the Netherlands East Indies government which appointed the first controller, J.A.M de Cats Baron de Raet, in Labuhan Deli. Soon after his appointment, de Raet rebuilt warehouses, which had been burned down completely not long

\footnotetext{
${ }^{1}$ Veth, P. J., "Het Lanschap Deli op Sumatra", TNAG, Deel II, 1877.

${ }^{2}$ Ratna, "Labuhan Deli: Riwayatmu Dulu", dalam Jurnal Historisme, Edisi No. 22/Tahun XI/Agustus 2006.

${ }^{3}$ Kathirittamby-Wells, J, "Hulu-hilir Unity and Conflict: Malay Statecraft inEast Sumatra before the MidNineteenth Century", dalam Archipe1, 1993.

${ }^{4}$ Anderson, John. (1971).Mission to the East Coast of Sumatra in 1823. New York: Oxford University.
} 
before his appointment, for storing commodities. He attempted to restore the trade life in Labuhan Deli. ${ }^{5}$ People then began to build shop houses with bricks at the right and left sides of the roads. Most of them were Chinese (about 1,000 people). ${ }^{6}$ Cats Baron de Rei held his position as a controller more than four years, and he recorded that trade activities and export/import in Labuhan Deli increased rapidly.

The Dutch Government began to seriously develop Labuhan Deli in 1875 by building office building functioning as the Customs House which examined ships and their cargo in and out of the seaport (SvNI, 1875). Although there was a custom house in each seaport, they only functioned to exploit the economic interest and was not managed properly and commercially.

Most of the exported commodities were forest products which were transported from the plantations in the hinterland by small boats along the river owned by Chinese merchants. The commodities were taken to Labuhan Deli as the transit before they were shipped to Malay peninsula (Penang and Malacca), Singapore, and the Netherlands. ${ }^{7}$ The shipping company which transported the commodities was Ocean Steam Ship \& Co, and the transportation to the Netherlands was monopolized by the Nederlandsch Indische StoombootMaatschappij (NISM).

The upstream of the Deli River could not be sailed since it was shallow, narrow, and swift; therefore, boats only reached as far as six miles, and small boats as far as 11 miles. ${ }^{8}$ The colonial government did dredging periodically, using dredger (bagermolen) along the river and its estuary. Dredging, of course, needed a lot of money and took a lot of time so that it was considered as ineffective and inefficient. Therefore, the Dutch Government and private companies began to think about building a coastal-seaport instead of a river-seaport. ${ }^{9}$

\subsection{Moving to Belawan}

Since transportation facility was considered inefficient and ineffective in transporting plantation products, DSM requested concession to the Netherlands East Indies government to construct railway track which connected hinterland plantations in Deli, Serdang, and Langkat with Medan and the seaport. The plan for constructing railway track was projected in such a way that the train could carry plantation commodities right away from plantations in the hinterland to the seaport and directly unloaded to the steam-ships, and vice versa. ${ }^{[2]}$

The community is very influential and, for that reason, the government should also be responsible for the survival and it's supporting facilities for a decent life. They also should provide the infrastructure to support the operation of economic, social, educational facilities to get the decent society. They has to support the society with a good quality service systems and regulatory policies such as public transportation services, facilitating the mobility of the community activities. All are related to an economic growth with the mobility of the population, the hustle and productivity of available regional resources (Sukesi and Yunus, 2018).

The projection was approved by the Governor General in Batavia so that feasibility study was commenced on soil structure, water depth, waves, and wind blowing, etc. After

\footnotetext{
5 Jaarverslag der Haven Belawan 1925, Werltreveden: Landsdrukkerij, 1926.

${ }^{6}$ Baron de Raet, J.A.M. van Cats.(1867). "Vergelijking van den Vroegeren Toestand van Deli, Serdang en Langkat", Tijdschrijft voor Indischhe Taal, Land, en Volkenkunde van Bataviasch Genootshap, Deel XII. Batavia: Albrecht\&co.

${ }^{7}$ Broersma, R. (1922). Oostkust van Sumatra: De Ontwikkeling van het Gewest, Deel II. The Hague: Charles Dixon Deventer.

${ }^{8}$ MvO Asisten-Residen Deli en Serdang, S. van der Plas, 1913.

${ }^{9}$ Jaarverslag der Haven Belawan 1925, Werltreveden: Landsdrukkerij, 1926
} 
that, they began to construct customs house, warehouses, and the other facilities. The railway tract from Labuhan Deli to Belawan was constructed in the $10^{\text {th }}$ of October, 1887 and finished in $1888 .^{10}$

After all supporting facilities had been completely built the test for loading and unloading to and from steam-ships in Belawan Harbor was done on the $5^{\text {th }}$ of January, 1888 , followed by the use of train. The activity was free from tax and tariff; they began to be imposed after the Customs House was officially opened in 1889. Belawan Harbor was officially operated in 1890 even though Labuhan Deli was still used as a seaport and owned by Kesultanan Deli. It was sailed by small ships and boats. ${ }^{11}$

\subsection{Development of Belawan Harbor}

As a new seaport which was prepared for regional and international shipping, Belawan harbor should have had supporting facilities for seaport activities such as wharf, open space for piling up goods (haventerrein), warehouses managed by the government and private companies, offices, private companies, and housing for employees and longshoremen. Besides that, it needed waterworks pipes, lighting, cranes, dredger (baggermolen), etc.

It was a private company, Ocean Steamship Company, which built some buildings for piling up commodities before being unloaded to ships. DSM built the wharf and the open space, and the East Sumatera Residency built the Customs House (tolkantoor).

After getting the license from the central government in Batavia, the extension of Belawan harbor was begun by clearing shrubs and reclaiming for building wharf, warehouses, and open space of about 667 and 10,084 square meters. In consequence, DSM had to move its railway track to the eastern part, and DSM felt harmed by the moving since it had just built it in 1888 so that the Government gave 142,000 guilden for compensation to DSM. ${ }^{12}$

Export and import activities had actually been done since 1887. At the time, many Chinese traders from Penang and Singapore did their trade through Belawan harbor while the government and plantations used Labuhan Deli since Belawan harbor had not completely did export and import activities. After it was officially opened in 1890, all export and import activities were done in Belawan harbor, and three years later (1893) tariffs and tax were imposed on traders. Many plantation commodities, especially tobacco, were exported through the harbor. Since the beginning of 1906, the use of Belawan harbor as the transit place for plantation products had been increasing rapidly so that warehouses were full of commodities; consequently, they had to be piled up on the open space which made their quality low. The government then extended the harbor by constructing new warehouses and wharf.

Long before Belawan harbor was used as a harbor for oceangoing vessels, it had had shipping network with European and American countries which imported plantation products from East Sumatera so that it became one of the new harbors in the Netherlands East Indies. ${ }^{13}$ The British, the Netherlands, and Germany were the three countries which had big shipping industry at the time, and shipping network of Belawan harbor with Penang, Singapore, and China was pioneered by private companies owned by the British and the German, while the shipping with moderate size ships to Penang and Singapore was pioneered by the Chinese. ${ }^{14}$

\footnotetext{
${ }^{10}$ Zeven en Veertigste Jaarverslag DSM, Statistiek van der Deli Spoorweg Maatshappij, Amsterdam: J.H. De Bussy, 1929.

${ }^{11}$ ANRI, Inventaris Arsip BOW No. 2114, "Nota van de Wenschelijkeheid tot het Maken van Een Oceanhaven te Belawan".

12 Cool, Wouter. (1917).Belawan-Oceaanhaven. Batavia: Departement der Burgerlike Openbare Werken Afdeeling Havenwezen.

${ }^{13}$ Dootjes, F. J. J., 1938, Kroniek 1937, Amsterdam: Oostkust van Sumatra Instituut.

14 Schadee, W. H. M., 1917, Kroniek 1916, Amsterdam: J. H. De Bussy.
} 
The shipping network from Belawan harbor to the European countries was directly carried out by the British shipping company, "The Eastern Shipping Company." The shipping company owned by Dutch government, KPM, also pioneered the shipping network from Belawan harbor to Rotterdam in order to compete with the British shipping companies. There were about 13 countries which had shipping network with Belawan harbor at the time.

The ships which frequently visited Belawan harbor were from Britain and the Netherlands since these two countries had a lot of ships at the time. However, there were also many ships from other countries such as Germany, the United States, Japan, Denmark, Sweden, and Norway, which also visited Belawan harbor for trading. From the statistical data of the ships which visited Beawan harbor in the period of 1922-1923, it was found that the British ships were more than the Dutch ships which visited Belawan harbor. However, from 1924 until 1935, the visit of the ships from the Netherlands increased to more than $500 \%$ which indicated that the Dutch government began to consider the competition between the Netherlands and Britain seriously.

The increase in the number of Dutch ships which visited Belawan harbor was closely related to the giving of monopoly to the shipping company, KPM, by the Dutch government. KPM was given the authority to serve short routes in the Malacca Strait. Realizing this opportunity, KPM began to extend its business by opening new branch offices in Sumatera. ${ }^{[5]}$ Another big shipping company in the Netherlands and the Netherlands East Indies was Rotterdamshe Llyod. This private company was able to compete with KPM which had been given the monopoly for short routes in the Netherlands East Indies.

\section{Conclusion}

An ideal place for a seaport is the one which location was somewhat protruded into the river or located at the two mouths of a river. Many traditional seaports like Labuhan Deli were located in such places. In the beginning, Labuhan Deli was the place where merchants got together bartering their goods. It then became bigger and bigger, and the authority began to use it as a seaport which location was protruded far into the estuary. It continuously functioned as a seaport until the period of Dutch colonialism, and the Dutch government finally moved export and import activities to Belawan harbor. Consequently, shipping and trade in East Sumatera was rapidly advancing which was closely related to the role of buffer zone of Belawan harbor, the hinterland and the foreland. These two buffer zones had indirectly made Belawan harbor livelier. The hinterland areas of Belawan harbor were small areas of plantations which were largely connected with the train lane to make easier transporting the plantation products to Belawan harbor. The foreland areas of Belawan harbor were the small seaports in East Sumatera and two international transit seaports, Penang and Singapore.

\section{Acknowledgment}

This article couldn't be published without financial support from "Penelitian DRPM Skema Penelitian Dasar Unggulan Perguruan Tinggi with the contract number 120/UN5.231/ PPM/KP-DRPM/2019. We also thanks to Lembaga Penelitan USU which has accommodated this research. Besides that, we also thanks to Arsip Nasional Republik Indonesia and Perpustakaan Nasional Republik Indonesia because the sources of this article are widely available there. 


\section{References}

Anderson, John. (1971).Mission to the East Coast of Sumatra in 1823. New York: Oxford University.

ANRI, Inventaris Arsip BOW No. 2114, "Nota van de Wenschelijkeheid tot het Maken van Een Oceanhaven te Belawan".

Baron de Raet, J.A.M. van Cats. (1867). "Vergelijking van den Vroegeren Toestand van Deli, Serdang en Langkat", Tijdschrijft voor Indischhe Taal, Land, en Volkenkunde van Bataviasch Genootshap, Deel XII. Batavia: Albrecht\&co.

Broersma, R. (1922). Oostkust van Sumatra: De Ontwikkeling van het Gewest, Deel II. The Hague: Charles Dixon Deventer.

Campo, J.N.F.M. a, 1992, De Konninklijk Paketvaart Maatschappij: Stoomvaart en Staatsvorming in de Indonesische Archipel 1888-1914, Hilversum: Verloren.

Cool, Wouter. (1917).Belawan-Oceaanhaven. Batavia: Departement der Burgerlike Openbare Werken Afdeeling Havenwezen.

Dootjes, F. J. J., 1938, Kroniek 1937, Amsterdam: Oostkust van Sumatra Instituut.

Jaarverslag der Haven Belawan 1925, Werltreveden: Landsdrukkerij, 1926.

Kathirittamby-Wells, J, "Hulu-hilir Unity and Conflict: Malay Statecraft inEast Sumatra before the Mid-Nineteenth Century", dalam Archipel, 1993.

MvO Asisten-Residen Deli en Serdang, S. van der Plas, 1913.

Ratna, "Labuhan Deli: Riwayatmu Dulu", dalam Jurnal Historisme, Edisi No. 22/Tahun XI/Agustus 2006.

Riyardi, A., et al. (2019). A Literature Review: Which Regulation is Feasible for Assessing User Satisfaction with Terminal Services? Budapest International Research and Critics Institute-Journal (BIRCI-Journal), P. 624-637.

Schadee, W. H. M., 1917, Kroniek 1916, Amsterdam: J. H. De Bussy.

Sukesi and Yunus, E. (2018). Service Quality in Public Transport Services of the Provicial Intercity Transportation (AKDP) in East Java Indonesia. Budapest International Research and Critics Institute-Journal (BIRCI-Journal), P. 161-169.

Veth, P. J., "Het Lanschap Deli op Sumatra", TNAG, Deel II, 1877.

Zeven en Veertigste Jaarverslag DSM, Statistiek van der Deli Spoorweg Maatshappij, Amsterdam: J.H. De Bussy, 1929. 